\title{
Gonadotrophins modulate hormone secretion and steady-state mRNA levels for activin receptors (type I, IIA, IIB) and inhibin co-receptor (betaglycan) in granulosa and theca cells from chicken prehierarchical and preovulatory follicles
}

\author{
Tristan M Lovell, Sara L Al-Musawi, Richard T Gladwell and Philip G Knight \\ School of Biological Sciences, University of Reading, Whiteknights, Reading, Berkshire RG6 6AJ, UK \\ Correspondence should be addressed to P G Knight; Email: p.g.knight@reading.ac.uk
}

\begin{abstract}
Ovarian follicle development is regulated through endocrine and local mechanisms. Increasing evidence indicates roles for transforming growth factor $\beta$ superfamily members, including inhibins and activins. We recently identified divergent expression of mRNAs encoding activin receptors (ActR) and inhibin co-receptor betaglycan in chicken follicles at different stages of maturation. Here, we compare the actions of LH and FSH $(0,1,10,100 \mathrm{ng} / \mathrm{ml})$ on levels of $\mathrm{mRNA}$ for ActRI, ActRIIA, ActRIIB and betaglycan in chicken granulosa and theca cells (GC and TC) from preovulatory (F1) and prehierarchical (6-8 mm) follicles. The expression of mRNAs for LH-R and FSH-R and production of inhibin A, oestradiol and progesterone were also quantified. FSH decreased ActRIIB and ActRI mRNA levels in 6-8 mm GC, whereas LH increased the mRNA levels. Both LH and FSH enhanced ActRIIA (5- and 8.5-fold) and betaglycan mRNA expression (2- and 3.5-fold) in 6-8 mm GC. In 6-8 $\mathrm{mm} \mathrm{TC}$, LH and FSH both increased the betaglycan mRNA level (7- and 3.5-fold respectively) but did not affect ActRI, ActRIIA and ActRIIB transcript levels. In F1 GC, both LH and FSH stimulated ActRI (2- and 2.4-fold), ActRIIB (3.2- and 2.7-fold) and betaglycan (7- and 4-fold) mRNA levels, while ActRIIA mRNA was unaffected. In F1 TC, LH and FSH reduced ActRIIA (35-50\%) and increased (4.5- and 7.6-fold) betaglycan mRNA, but had no effect on ActRI and ActRIIB transcript levels. Results support the hypothesis that expression of ActR and betaglycan are differentially regulated by gonadotrophins during follicle maturation in the hen. This may represent an important mechanism for fine-tuning follicle responsiveness to local and systemic activins and inhibins.
\end{abstract}

Reproduction (2007) 133 1159-1168

\section{Introduction}

The avian ovary provides a unique model for the study of folliculogenesis. The single functional left ovary typically contains approximately six (F1-F6) preovulatory follicles arranged in a strict size hierarchy with follicles committed to ovulate at intervals of $24-26 \mathrm{~h}$. After ovulation of the largest (F1) follicle, the succeeding follicles each move up one place in the hierarchy and an additional follicle is recruited from the population of small yellow $(6-8 \mathrm{~mm}$ diameter $)$ prehierarchical follicles. Prehierarchical follicles undergo a higher rate of atresia than preovulatory follicles (Gilbert et al. 1983). Various ligands including inhibins (Inh), activins (Act), steroids (Bahr \& Johnson 1984, Lovell et al. 1998) and receptors including activin receptors (ActR; Lovell et al. 2006), inhibin co-receptor (betaglycan, Bgly; Sweeney \& Johnson 2005, Lovell et al. 2006) and receptors for the gonadotrophins luteinizing hormone and follicle-stimulating hormone (LH-R, FSH-R; Johnson et al. 1996, You et al. 1996) are also expressed to different extents by granulosa and theca cells (GC and TC) of prehierarchical and preovulatory follicles.

$\mathrm{LH}$ and $\mathrm{FSH}$ play key roles in regulating ovarian dynamics through stimulation of steroidogenesis, production of peptide hormones (including Inh and Act), cell proliferation (Bahr \& Johnson 1984, Tilly et al. 1991, Johnson 1993, Lovell et al. 2002a) and apoptosis (Johnson et al. 1999) through specific $\mathrm{LH}$ and FSH receptors (Johnson et al. 1996, You et al. 1996). Inh and Act have been implicated as direct (paracrine/autocrine) and indirect (endocrine) regulators of ovarian development in birds (Davis et al. 2001, Johnson et al. 2004; review: Knight et al. 2005) and mammals (reviews: Knight \& Glister 2003, Philips 2005). 
The action of Act is elicited through a wellcharacterised signal transduction cascade (review Abe et al. 2004). Act can bind with high affinity to a type-II cell-surface receptor (ActRII) of which two have been cloned in avian (Ohuchi et al. 1992, Nohno et al. 1993, Stern et al. 1995) and mammalian species (Donaldson et al. 1992, Stern et al. 1995). Binding promotes the recruitment of activin type-I receptors (ActRI) to the complex which is then able to mediate ligand-dependent signalling by Smads (Knight \& Glister 2003, Abe et al. 2004). Bgly (also known as transforming growth factor $\beta$ (TGF $\beta$ ) III receptor) is a membrane-bound proteoglycan, which can bind inhibin and increase its affinity for ActRII (Lewis et al. 2000). This Inh/Bgly/ActRII complex is thought to prevent binding of Act to the ActRII and thereby block the recruitment of ActRI and activin-stimulated signal transduction (Phillips \& Woodruff 2004).

During follicle development in the laying hen, changes have been observed in Inh/Act subunit mRNA expression (Davis \& Johnson 1998, Knight et al. 2005), InhA, InhB, ActA and follistatin protein content (FS; Lovell et al. 1998, 2003) and expression of mRNAs for ActR (type I, IIA, IIB; Lovell et al. 2006) and BGly (Sweeney \& Johnson 2005, Lovell et al. 2006). ActRIIA mRNA expression has also been shown (by Northern blot) to change throughout follicle development in broiler breeder hens (Slappey \& Davis 2003). This suggests a functional involvement of the intraovarian Inh-Act system in follicle progression. Similarly, marked differences in steroidogenic capacity (Etches \& Duke 1984, Kato et al. 1995) and mRNA expression of gonadotrophin receptors (LH-R, FSH-R; Johnson et al. 1996, You et al. 1996) have been recorded within both GCs and TCs during follicle development in birds.

The observation that treatment of hen preovulatory follicle GCs with ActA greatly enhanced gonadotrophininduced InhA and progesterone (P4) release suggests a functional interaction between gonadotrophin-dependent and Act-dependent signalling pathways (Lovell et al. 2002a). In support of this, ActA was recently shown to enhance the expression of both FSH-R and LH-R in GC from preovulatory follicles (Johnson et al. 2006). There are other reports (Johnson et al. 2004, 2006, Woods \& Johnson 2005) that ActA augments gonadotrophin receptor mRNA expression in granuolsa cells from prehierarchical (small yolky) hen follicles.

With the above findings in mind, the primary aim of the present study was to test the hypothesis that pituitary gonadotrophins differentially modulate granulosal expression of ActRs and Bgly mRNAs at two key stages of folliculogenesis: prehierarchical and preovulatory. In the absence of comparable studies on avian TC, we also conducted parallel experiments to determine the effects of gonadotrophins on TC from both prehierarchical and preovulatory follicles.

\section{Materials and Methods}

\section{Experimental animals}

Laying hens (Goldline) towards the end of the first year of lay, with a clutch average of at least five eggs, were caged individually and maintained as required by the United Kingdom Home Office Regulations. Hens were kept on a standard long-day photo-schedule of $16 \mathrm{~h}$ light: $8 \mathrm{~h}$ darkness cycle, at an ambient temperature of $21-23^{\circ} \mathrm{C}$. Food and water were available ad libitum. Ovipositions were monitored using time-lapse recording technology and used to predict the time of ovulation. Hens $(n=5-6$ different hens per culture) were killed by cervical dislocation $\sim 12 \mathrm{~h}$ after ovulation of a mid-sequence egg and the largest preovulatory follicle (F1) and all 6-8 $\mathrm{mm}$ prehierarchical follicles were removed and placed immediately in sterile Hank's Balanced Salt Solution (HBSS; Gibco-BRL).

\section{Isolation of granulosa and theca cells}

Granulosa and theca layers were separated under aseptic conditions (Gilbert et al. 1977). In brief, granulosa and thecal tissue derived from a given follicle position in different hens were combined (creating separate granulosa and theca follicle pools from the $6-8 \mathrm{~mm}$ and the F1 follicles). Pooled tissues were enzymatically dispersed as described by Lovell et al. (2002b) except that thecal tissue was dispersed for a further $15 \mathrm{~min}$ (total: $45 \mathrm{~min}$ ). It should be noted that the theca tissue collected for dispersion consists of the theca interna and theca externa layers and therefore all the different cell types these layers may contain in vivo. The number of viable cells, estimated by trypan blue exclusion (Sigma UK Ltd), was invariably $>90 \%$ for both the cell types. Isolated cells were diluted in incubation medium (medium 199 with $25 \mathrm{mM}$ Hepes, $0.01 \%(\mathrm{v} / \mathrm{v})$ L-glutamine and $1 \% \quad(\mathrm{v} / \mathrm{v})$ antibiotic solution) containing $2 \% \quad(\mathrm{v} / \mathrm{v})$ charcoal-stripped fetal calf serum (Sigma UK Ltd) and divided into aliquots in 24-well plates (Falcon 3047; Becton Dickinson Labware, Franklin Lakes, NJ, USA) at $5 \times 10^{5}$ viable cells per well. The cells were maintained for $24 \mathrm{~h}$ at $39{ }^{\circ} \mathrm{C}$ and the unattached cells were aspirated off and the adherent cells were washed three times with $1 \mathrm{ml}$ serum-free incubation medium. All further incubations were done in serum-free conditions. Incubation buffer $(1 \mathrm{ml})$ and test treatments were added to the appropriate wells. The cells were incubated for $2 \times 24 \mathrm{~h}$ treatment periods with the media replenished with the appropriate test treatments after $24 \mathrm{~h}$. At termination of the culture, the media were removed and stored at $-20{ }^{\circ} \mathrm{C}$ and the cell monolayers were washed three times with PBS (Oxoid Ltd, Basingstoke, Hampshire, UK) before lysis in Tri-reagent (Sigma UK Ltd). 


\section{Treatments}

Stock solutions of ovine (o)LH (NIDDK-oLH-25) and oFSH (NIDDK-oFSH-19-SIAPH) were prepared at $10 \mu \mathrm{g} / \mathrm{ml}$ in HBSS containing $0.3 \%(\mathrm{v} / \mathrm{v})$ BSA (fraction $\mathrm{V}$; Sigma UK Ltd). Before culture, the treatments were diluted in the above incubation medium, to a $40 \times$ treatment concentration and filter sterilised using a $0.2 \mu \mathrm{M}$ Millipore filter (FlowPore D; ICN Biomedicals Ltd, Basingstoke, Hampshire, UK). Both gonadotrophins were tested at final concentrations of 1,10 and $100 \mathrm{ng} / \mathrm{ml}$.

\section{RNA purification and CDNA synthesis}

RNA was purified from cell monolayers according to the standard Tri-reagent protocol (Sigma UK Ltd). The final RNA pellet was resuspended in $100 \mu$ nuclease-free water containing RNA Secure (Ambion, Huntington, Cambridgeshire, UK) and then treated with RNase-free DNAse $\left(15 \mathrm{~min}\right.$ at $37^{\circ} \mathrm{C}$; RQ1, Promega) to remove potential genomic DNA contamination. The RNA preparation was re-purified using 15 volumes Trireagent. The resultant purified RNA was resuspended in $50 \mu \mathrm{l}$ nuclease-free water containing RNA Secure.

RNA was quantified on a spectrophotometer (GeneQuant, GE Healthcare UK Ltd, Amersham) and cDNA was synthesised using ImProm-II Reverse Transcriptase (Promega; used according to the Manufacturers instructions) with $1 \mu \mathrm{g}$ RNA, $0.5 \mu \mathrm{g}$ Random Hexamer Primers (MWG-Biotech, Covent Garden, London, UK), dNTPS (0.5 mM Final; Promega) and $0.5 \mu \mathrm{l}$ RNase-inhibitor $(40 \mathrm{U} / \mu \mathrm{l}$; Ambion) per reaction. cDNA synthesis was terminated by heat-inactivation $\left(15 \mathrm{~min}\right.$ at $\left.70{ }^{\circ} \mathrm{C}\right)$. cDNA samples were treated with $1 \mu \mathrm{l}$ RNase cocktail $(0.5 \mathrm{U} / \mu \mathrm{l}$ RNase $\mathrm{A}$ and $20 \mathrm{U} / \mu \mathrm{l}$ RNase T1; Ambion) and $0.5 \mu \mathrm{l}$

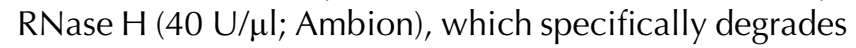
the RNA in RNA:DNA hybrids. A $1 \mu$ l aliquot of cDNA was removed for estimation using a fluorometric assay (Oligreen ssDNA Quantification assay; Molecular Probes Inc., Paisley, Renfrewshire, UK).

\section{Quantitative PCR}

Duplicate Q-PCRs were carried out using $1 \mu \mathrm{l}$ RT reaction product or $1 \mu \mathrm{l}$ standard (from 200 to
$1.56 \mathrm{amol} / \mu \mathrm{l}$; standard oligonucleotides were customsynthesised by Sigma-Genosys), in a volume of $25 \mu \mathrm{l}$ containing $12.5 \mu \mathrm{l}$ master mix with $1 \mu \mathrm{l}$ ROX dye (Abgene, Epsom, Surry, UK), $2 \mu \mathrm{l}$ forward and reverse primers were each added (final concentration: 300-900 $\mathrm{nM}$ ), $1 \mu \mathrm{l}$ probe (final concentration: 100-200 nM) and $5.5 \mu$ l nuclease-free water. All forward and reverse primer working concentrations were $900 \mathrm{nM}$ except the forward primer for GAPDH (300 nM). Probe working concentrations were $200 \mathrm{nM}$ except for $\mathrm{LH}-\mathrm{R}$ $(150 \mathrm{nM}), \mathrm{FSH}-\mathrm{R}(150 \mathrm{nM})$ and GAPDH $(100 \mathrm{nM})$. The samples were processed for 40 cycles using an $A B I$ Prism 7700 Sequence detector (Applied Biosystems, Warrington, Cheshire, UK) with the thermal cycler conditions; stage 1: $50{ }^{\circ} \mathrm{C} / 2 \mathrm{~min}$, stage $2: 95^{\circ} \mathrm{C} / 15 \mathrm{~min}$, stage $3: 40$ cycles of $95^{\circ} \mathrm{C} / 15 \mathrm{~s}$ and $60^{\circ} \mathrm{C} / 1 \mathrm{~min}$. TaqMan primers and probes were designed to target mRNA sequences based on criteria set by Applied Biosystems. Probes were 5'-modified with 6-FAM and 3'-modified with TAMRA. Primer and probe sequences and target mRNA accession numbers are presented in Table 1. Intra- and inter-plate coefficients of variation (CV) for each Q-PCR assay (ActRI, ActRIIA, ActRIIB, LHR, FSHR, betaglycan and GAPDH) were between $0.9-1.5 \%$ and $7.4-10.2 \%$ respectively. Intra-assay $\mathrm{CV}$ values were based on independent $(n=30)$ Ct sample values across a single Q-PCR plate, whereas inter-assay CVs were based on the calculated concentrations of pre-aliquoted quality control samples tested on independent Q-PCR plates $(n=4)$.

\section{Immunoassays}

Cell-conditioned media (CM) were assayed for InhA using a specific two-site ELISA that uses monoclonal antibodies raised against synthetic peptide fragments of the human $\alpha$ - and $\beta A$-subunits (Muttukrishna et al. 1994). This assay has been validated for domestic fowl as described by Lovell et al. (1998). Recombinant human InhA was used as an assay standard (detection limit 2 pg/well). The ELISA showed minimal $(<0.3 \%)$ cross-reaction with bovine inhibin $\alpha$-subunit $(200 \mathrm{ng} / \mathrm{ml})$, rh inhibin-B $(10 \mathrm{ng} / \mathrm{ml})$, activin-A $(10 \mathrm{ng} / \mathrm{ml})$, follistatin $(20 \mathrm{ng} / \mathrm{ml})$. When tested at 1,10 and $100 \mathrm{ng} / \mathrm{ml}$, the ovine $\mathrm{FSH}$ and $\mathrm{LH}$ preparations used in the study showed no detectable cross-reaction $(<0.002 \%)$ in the inhA ELISA.

Table 1 TaqMan primer and probe sequences used in the study.

\begin{tabular}{|c|c|c|c|c|}
\hline Target & Forward primer $5^{\prime}$ to $3^{\prime}$ & Reverse primer $5^{\prime}$ to $3^{\prime}$ & $\begin{array}{c}\text { TaqMan probe } 5^{\prime}\left(6-\text { FAM) to } 3^{\prime}\right. \\
\text { (TAMRA) }\end{array}$ & Accession number \\
\hline Activin type I receptor & ccggaggtcttggacgaaa & gcccagatatcgaccctcttg & catccaggcagactgcttcgactcc & AJ318064 \\
\hline Activin type IIA receptor & tcacgaaaagggttcattaactga & ctgagcaatgtgacacagctcat & ttcctcaaggctaacgtggtttcctgg & D31899 \\
\hline Activin type IIB receptor & tccctgcttaacatcctggtgta & ccaagaggatggccactga & tctctgctgcccatcgctgtcct & U31223 \\
\hline Betaglycan & atgaagcttgcacctctctgaat & gacaagaggcttggtgaaggttt & tggatatgatcttggccatgatgcaca & L01121 \\
\hline LH receptor & ttcttcaacggcactggagtc & tccaggtcctcaatgcaatg & ctgcctagctatgggctggaggcc & NM204936 \\
\hline FSH receptor & ccgggacattcccacca & gatgagagtcattccgaaggga & tgccacagaactgagatttgtcctcacca & NM205079 \\
\hline GAPDH & ggagtcaacggatttggcc & $\begin{array}{l}\text { tttgccagagaggacggc } \\
\text { tto }\end{array}$ & tattggccgcctggtcaccagg & K01458 \\
\hline
\end{tabular}


P4 and oestradiol (E2) concentrations were determined by direct RIA as described by Sauer et al. (1986) and Tannetta et al. (1998) respectively. The detection limits of the assays were 8 and $1.5 \mathrm{pg} / \mathrm{ml}$ respectively. Intra- and inter-assay coefficients of variation for each assay were $<10 \%$. Attempts were made to quantify secretion of InhB, ActA and FS in selected GC and TC culture experiments (Methods as described in Lovell et al. 1998, 2000, 2003). However, levels were below the detection limit of each assay (15 pg/well, $50 \mathrm{pg} /$ well and $0.6 \mathrm{ng} /$ well respectively).

\section{Statistical analysis}

One-way ANOVA was used in conjunction with post hoc Fisher's protected least significant difference (PLSD) test to evaluate treatment effects on levels of mRNA encoding receptors and on hormone release by each of the different follicle GC and TC populations $(6-8 \mathrm{~mm}$ and F1 follicle). Two-way ANOVA was used to make comparisons between the effects of treatments on the different cell populations. Levels of mRNA for each receptor were normalised to GAPDH. A value of $P<0.05$ was considered significant. There was no significant difference (ANOVA; $P>0.05$ ) in GAPDH mRNA transcript levels between the GC and the TC cultures of different follicle classes or following treatment with $\mathrm{LH}$ or FSH. Hormone secretion results presented are for the final $24 \mathrm{~h}$ period of culture. In a given experiment, treatments were tested using triplicate wells which were pooled for RNA isolation within a given culture and each experiment was repeated using at least three independent cultures (utilising independently isolated cell preparations). All values presented are means \pm S.E.M. (with $n$ indicating the number of independent cultures).

\section{Results}

The expression of mRNAs for the three ActRs (ActR-I, IIA, -IIB), $\beta g l y, ~ F S H-R$ and $\mathrm{LH}-\mathrm{R}$ was readily detectable in the $\mathrm{GC}$ and TC from both follicle stages under investigation (6-8 $\mathrm{mm}$ and F1). In contrast, oestradiol was only detectable in TC-CM, whereas $\mathrm{P} 4$ was predominantly produced by the F1 GC.

\section{Effect of $L H$ and FSH on mRNA for ActRI, ActRIIA, ActRIIB, $\beta$ gly, LH-R and FSH-R in GCs from 6 to $8 \mathrm{~mm}$ follicles $(6-8 G C)$}

Changes in the 6-8GC expression of mRNAs encoding ActRs (ActR-I, -IIA, -IIB) and Bgly during culture with LH or FSH are shown in Fig. 1. LH treatment $(100 \mathrm{ng} / \mathrm{ml})$ caused a significant $(P<0.05 ; 83 \%)$ increase in ActRI mRNA transcript level, whereas FSH $(100 \mathrm{ng} / \mathrm{ml})$ promoted a decrease $(P<0.05 ; 65 \%)$. FSH $(10-100 \mathrm{ng} / \mathrm{ml}$;

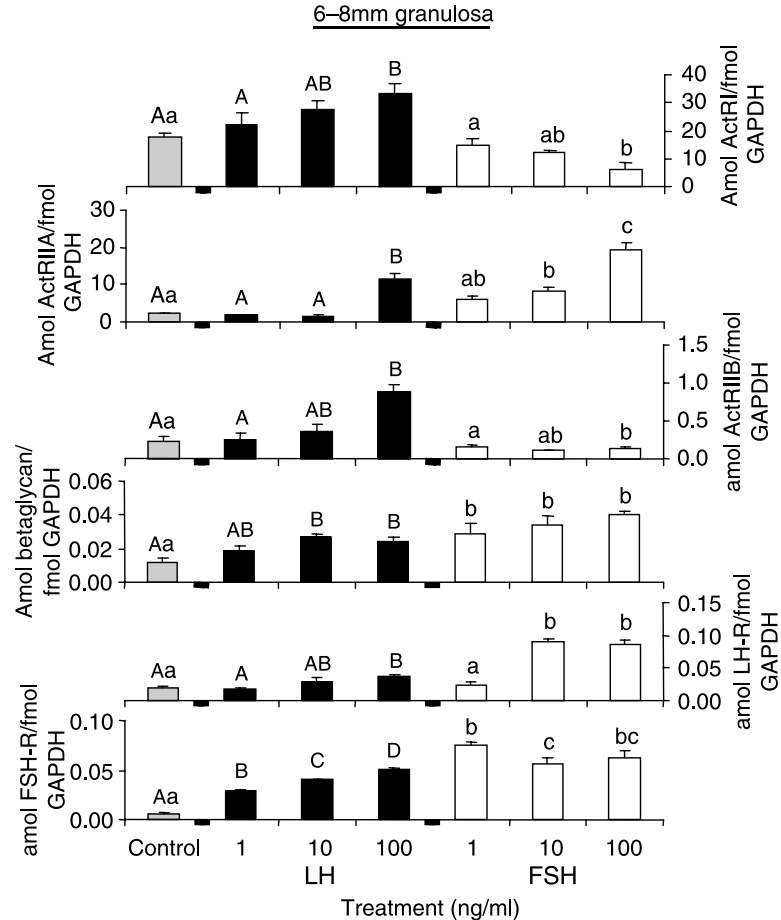

Figure 1 Effects of $\mathrm{LH}$ and FSH on mRNA levels for ActRI, ActRIIA, ActRIIB, $\beta$ gly, FSH-R and LH-R in granulosa cells isolated from $6-8 \mathrm{~mm}$ ovarian follicles. Values are means \pm s.E.M. $(n=3-5$ independent cultures) and means without a common letter (case-specific) are significantly $(P<0.05)$ different (by ANOVA and Fisher's PLSD test). Upper and lower case letters show a significant difference with LH treatment (black columns) and FSH treatment (white columns) respectively.

3.7-8.5-fold) and LH (100 ng/ml; 8.5-fold) significantly increased the ActRIIA mRNA level. Changes in ActRIIB mRNA with $\mathrm{LH}$ and $\mathrm{FSH}$ treatment paralleled ActRI transcript; $100 \mathrm{ng} / \mathrm{ml} \mathrm{LH}$ increased significantly $(P<0.01$; 3.7-fold), while $100 \mathrm{ng} / \mathrm{ml} \mathrm{FSH}$ decreased significantly $(P<0.05 ; 57 \%)$ ActRIIB transcript. Bgly mRNA level was significantly $(P<0.01)$ increased by LH (10-100 ng/ml; by up to twofold) and FSH (1-100 ng/ml; by up to 3.5 -fold). FSH $(10-100 \mathrm{ng} / \mathrm{ml})$ significantly increased $(4.5$-fold; $P<0.0001)$ the LH-R mRNA expression in 6-8GC. All doses of FSH increased FSH-R transcript (eight- to tenfold) when compared with controls. LH also caused a dose-dependent increase in FSH-R mRNA expression (up to eightfold).

\section{Effect of LH and FSH on mRNA for ActRI, ActRIIA, ActRIIB, $\beta g l y, L H-R$ and FSH-R in TCs from 6 to $8 \mathrm{~mm}$ follicles (6-8TC)}

Changes in the 6-8TC expression of mRNAs encoding (ActR-I, -IIA, -IIB) and betaglycan are shown in Fig. 2. Neither LH nor FSH significantly altered the mRNA expression of ActRI, ActRIIA or ActRIIB $(P>0.05)$. However, both LH and FSH significantly $(P<0.05)$ 


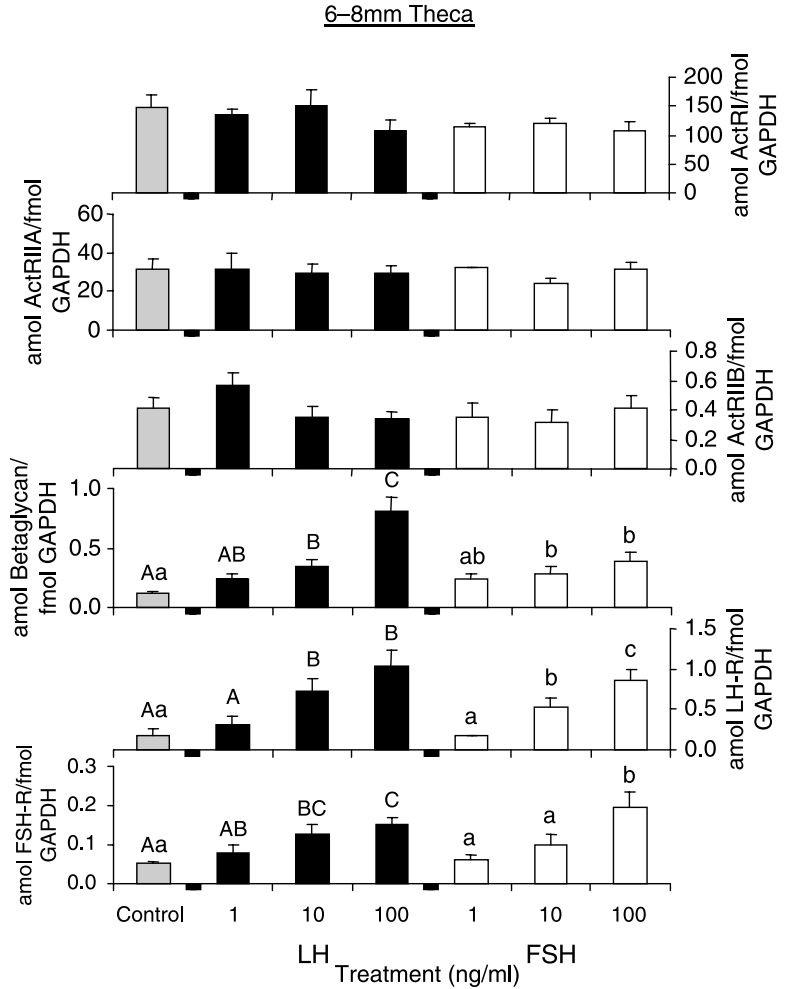

Figure 2 Effects of $\mathrm{LH}$ and FSH on mRNA levels for ActRI, ActRIIA, ActRIIB, Bgly, FSH-R and LH-R in theca cells isolated from $6-8 \mathrm{~mm}$ ovarian follicles. Other details are the same as given in the legend to Fig. 1.

increased the $\beta$ gly transcript level (7- and 3.5-fold respectively). FSH-R mRNA expression in 6-8TC was stimulated by both $\mathrm{LH}$ (threefold) and FSH (fourfold) at $100 \mathrm{ng} / \mathrm{ml}$. LH and FSH also stimulated LH-R transcript levels in 6-8TC (5.6- and 4.7-fold respectively).

\section{Effect of LH and FSH on mRNA for ActRI, ActRIIA, ActRIIB, $\beta g l y, L H-R$ and FSH-R in GCs from F1 follicles (F1 GC)}

Changes in the levels of mRNAs encoding ActRs and Bgly in the F1 GC are shown in Fig. 3. ActRI mRNA expression was increased by both LH (10-100 ng/ml; twofold) and FSH (100 ng/ml; 2.4-fold). ActRIIA transcript level was not significantly altered by $\mathrm{LH}$ or FSH treatment. ActRIIB mRNA expression was increased dose-dependently by FSH (up to 2.7-fold; $P<0.01$ ), whereas only $100 \mathrm{ng} / \mathrm{ml}$ LH significantly increased expression (3.2-fold). Bgly mRNA level was also significantly $(P<0.001)$ increased by $\mathrm{LH}(100 \mathrm{ng} / \mathrm{ml}$; sevenfold) and $\mathrm{FSH}(100 \mathrm{ng} / \mathrm{ml}$; fourfold). The expression of LH-R mRNA in F1 GC was increased approximately twofold by LH (10-100 ng/ml) while FSH had no significant effect. In contrast, FSH-R mRNA expression was slightly increased by $\mathrm{FSH}(40 \% ; 100 \mathrm{ng} / \mathrm{ml} ; P<$ 0.05) while LH had no effect.

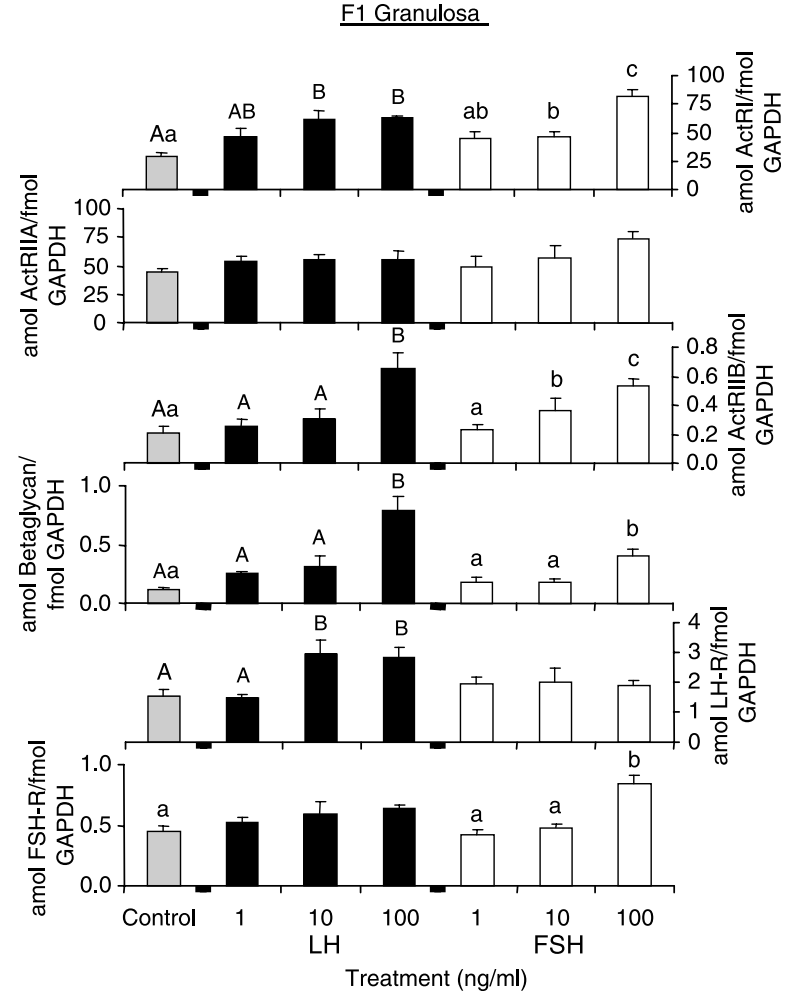

Figure 3 Effects of LH and FSH on mRNA levels for ActRI, ActRIIA, ActRIIB, $\beta$ gly, FSH-R and LH-R in granulosa cells isolated from the largest (F1) preovulatory follicle. Other details are the same as given in the legend to Fig. 1.

\section{Effect of LH and FSH on mRNA for ActRI, ActRIIA, ActRIIB, $\beta g l y, L H-R$ and FSH-R in TCs from F1 follicles (F1 TC)}

Changes in the $\mathrm{F} 1 \mathrm{TC}$ expression of mRNAs encoding ActRs (ActR-I, -IIA, -IIB) and betaglycan are shown in Fig. 4. Neither LH nor FSH affected the expression of ActRI and ActRIIB mRNA $(P>0.05)$ although they slightly reduced the ActRIIA mRNA expression by $35-50 \% \quad(P<0.01)$. LH and FSH dose-dependently increased $\beta$ gly transcript level by 4.5 -fold $(P<0.05)$ and 7.6-fold $(P<0.0001)$ respectively. In $\mathrm{F} 1 \mathrm{TC}$, unlike in F1 GC, expression of $\mathrm{FSH}-\mathrm{R}$ transcript was increased twofold by $\mathrm{LH}$ (at $100 \mathrm{ng} / \mathrm{ml}$ ) but FSH had no effect. In contrast, LH-R mRNA expression in F1 TC was increased by both $\mathrm{LH}$ (up to fivefold) and FSH (up to 2.5 -fold).

\section{Comparison between prehierarchical and preovulatory follicles: basal and gonadotrophin-induced expression of $\mathrm{mRNA}$ for ActR and $\beta$ gly}

Two-way ANOVA of ActRI and ActRIIB transcript data revealed that GC from the two follicle types responded very differently to $\mathrm{FSH}$ treatment $(P<0.0001)$; whereas $\mathrm{FSH}$ promoted a significant reduction in mRNA 


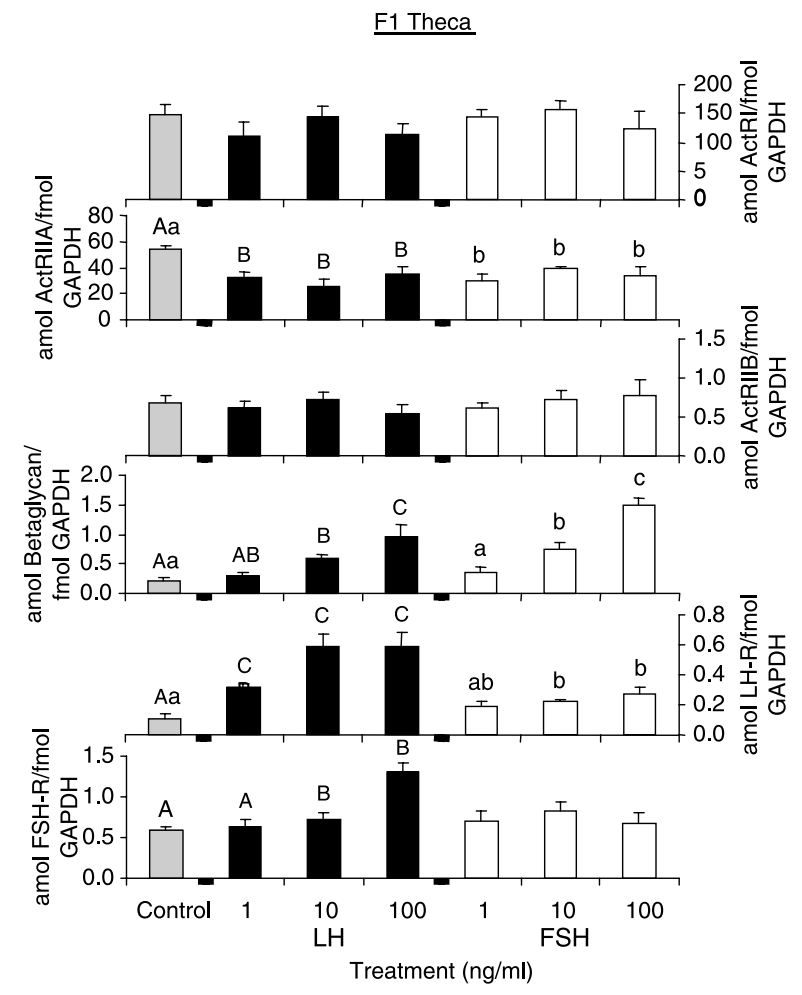

Figure 4 Effects of $\mathrm{LH}$ and FSH on mRNA levels for ActRI, ActRIIA, ActRIIB, $\beta$ gly, FSH-R and LH-R in theca cells isolated from the largest (F1) preovulatory follicle. Other details are the same as given in the legend to Fig. 1.

expression in the 6-8GC, transcript levels were increased in the F1 GC. No corresponding difference was found in the $\mathrm{GC}$ response to $\mathrm{LH}$ for these two receptors $(P>0.05$, two-way ANOVA), although ActRI mRNA expression was significantly higher in the F1 GC than in 6-8GC $(P<0.05)$. LH and FSH had no effect on thecal ActRI and ActRIIB mRNA expression; however, levels of ActRIIB transcript was significantly higher in the F1 TC than in 6-8TC (two-way ANOVA).

ActRIIA mRNA expression in both GC and TC was significantly higher in the $\mathrm{F} 1$ than in $6-8 \mathrm{~mm}$ follicles. However, only 6-8GC ActRIIA mRNA expression was significantly increased by $\mathrm{LH}$ and $\mathrm{FSH}(P<0.0001)$. In contrast, ActRIIA mRNA expression in the F1 TC, but not 6-8 mmTC, was significantly $(P<0.01)$ reduced by $\mathrm{LH}$ and FSH treatment.

Bgly mRNA expression in 6-8GC+ TC and F1 GC+ TC was positively regulated by $\mathrm{LH}$ and $\mathrm{FSH}$. The levels of $\beta$ gly transcript were maximal with $\mathrm{LH}$ in $\mathrm{F} 1 \mathrm{GC}$ and with $\mathrm{FSH}$ in 6 -8G. The $\beta$ gly mRNA expression in F1 TC was stimulated by $\mathrm{LH}$ to a lesser extent than $\mathrm{FSH}$ (4.5-fold vs 7-fold), while in 6-8TC LH was more stimulatory than FSH (7.2-fold vs 3.5-fold; $P<0.01$ ).

Analysis using multifactorial ANOVA demonstrated that TC Bgly mRNA expression within $6-8 \mathrm{~mm}$ follicles was significantly higher $(P<0.05)$ than in the corresponding GC following $\mathrm{LH}$ and $\mathrm{FSH}$ stimulation. F1 TC Bgly mRNA expression was also significantly higher than in the corresponding GC following FSH stimulation, although there was no significant difference following LH stimulation.

\section{Effect of $L H$ and FSH on the release of InhA, P4 and E2 by $6-8 \mathrm{~mm}$ and $\mathrm{F1} \mathrm{GC}$ and TC}

The release of InhA, P4 and E2 in response to $\mathrm{LH}$ and FSH treatment in $6-8 \mathrm{~mm}$ and $\mathrm{F} 1 \mathrm{GC}$ and $\mathrm{TC}$ is shown in Fig. 5. Basal InhA levels in 6-8GC media were below the assay detection limit $(2 \mathrm{pg} / \mathrm{ml})$; however, following stimulation by LH (all doses) and FSH $(10-100 \mathrm{ng} / \mathrm{ml})$, InhA levels increased to

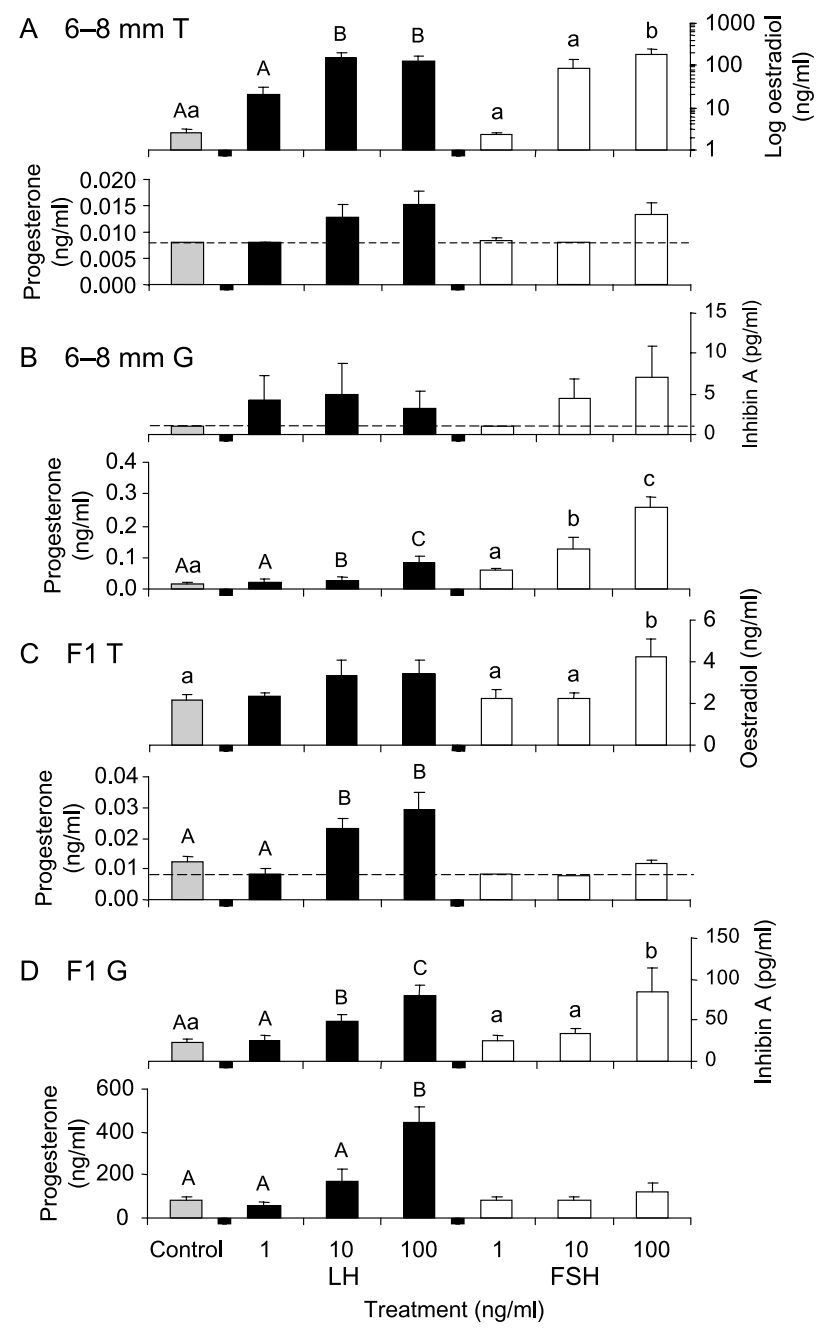

Figure 5 Effects of $\mathrm{LH}$ and $\mathrm{FSH}$ on the secretion of inhibin $\mathrm{A}$, progesterone and oestradiol by cultured cells derived from (A) theca and (B) granulosa cells from 6-8 mm follicles and (C) theca and (D) granulosa cells from the largest (F1) follicle. Thecal inhibin A and granulosal oestradiol secretion (basal and stimulated) are not plotted as values were below the assay detection limit in both the $6-8 \mathrm{~mm}$ and F1 follicle classes. The dashed line represents the detection limit of the assay. Other details are the same as given in the legend to Fig. 1. 
detectable levels (Fig. 5B). LH and FSH both elicited marked dose-dependent increases in $\mathrm{P} 4$ release by 6-8GC (5.6-fold and 17.3-fold respectively; $P<0.001$ ). Conversely, LH promoted a greater $\mathrm{P} 4$ increase than FSH in F1 GC (5-fold vs 1.5 -fold; $P<0.05$ by two-way ANOVA). It should be noted that basal $\mathrm{P} 4$ release was some 1000 times greater for F1 GC when compared with 6-8GC. $\mathrm{LH}$ and FSH treatment of F1 GC also significantly increased InhA release (up to fourfold; $P<0.05)$. E2 was undetectable in GC-CM under all treatment conditions.

Treatment of 6-8TC with LH or FSH dose-dependently increased $(P<0.001)$ E2 release up to 46 -fold and 73-fold respectively (Fig. 5A). E2 release by F1 TC was much lower than in 6-8TC and only a slight response to FSH was observed (Fig. 5C). Basal P4 levels in both 6-8TC and F1 TC CM were at or below the assay detection limit $(8 \mathrm{pg} / \mathrm{ml})$ but rose to detectable levels following $\mathrm{LH}$ or FSH treatment. As in F1 GC, FSH had no effect on P4 release in F1 TC. It should be noted that basal- and LH-stimulated P4 release from F1 GC were $\sim 6500$-fold and 15000 -fold respectively, higher than from F1 TC.

\section{Discussion}

Consistent with immunocytochemical evidence that ActRI, ActRIIA, ActRIIB and Bgly proteins are expressed in GC from hen ovarian follicles (Lovell et al. 2002a, Sweeney \& Johnson 2005), the present study shows that mRNA transcripts for ActRI, ActRIIA, ActRIIB and Bgly are detectable within cultured GC and TC derived from both prehierarchical $(6-8 \mathrm{~mm})$ and preovulatory $\mathrm{F} 1$ follicles. Moreover, we demonstrate that pituitary gonadotrophins ( $\mathrm{LH}$ and $\mathrm{FSH}$ ) modulate these receptor transcripts within GC and TC at both follicle stages.

A quantitative assessment of receptor protein expression under the different experimental conditions was beyond the scope of this study but previous in vitro studies on chicken GCs clearly support the presence of functional type-I and -II ActRs that are capable of forming active signalling complexes. Lovell et al. (2002a) shown that ActA ( $\beta$ A- $\beta$ A dimer, which is mainly confined to TC in chickens; Lovell et al. 1998, 2003) enhanced gonadotrophin-induced secretion of InhA $(\alpha-\beta A$ dimer) and P4 by GC from hen preovulatory follicles. ActA also enhanced FSH-R and LH-R mRNA expression in GC from preovulatory follicles (Johnson et al. 2006). An ActA-induced increase in FSH-R mRNA expression has also been observed in GC from preheirarchical hen follicles (Johnson et al. 2004, 2006, Woods \& Johnson 2005).

Within the hen GC layer, there is a developmental shift from an $\mathrm{FSH}$ - to an $\mathrm{LH}$-dependent mechanism of regulating follicular development as follicles are selected (Tilly et al. 1991, Johnson et al. 1996, You et al. 1996), similar to that occurring in mammals
(Richards 1994). Of key interest in this regard are the findings that $\mathrm{FSH}$ reduced and $\mathrm{LH}$ increased both ActRIIB and ActRI mRNA transcript levels within GC of 'unselected' prehierarchical $(6-8 \mathrm{~mm})$ follicles, whereas both $\mathrm{LH}$ and $\mathrm{FSH}$ stimulated mRNA expression of both receptors in 'selected' F1 GC. We hypothesise that it is this shift in the response to FSH and $\mathrm{LH}$ of ActR mRNA expression that modulates this responsiveness of cells to intrafollicular activin.

As it has been shown that ActA increased LH-R mRNA expression in 6-8 mmGC (Johnson et al. 2004), the present and previous data lead us to propose that GC of prehierarchical follicles approaching selection, which are primarily FSH-driven, have reduced expression of key ActRs (ActRI and ActRIIB) and therefore a diminished responsiveness to Act. In turn, as follicles are selected and become more responsive to $\mathrm{LH}, \mathrm{ActRI}$ and ActRIIB mRNA expression is upregulated leading to greater co-stimulation by Act. Indeed, ActA can further stimulate LH-R mRNA expression in 6-8 mm GC (Johnson et al. 2004), which could lead to a further increase in LH-responsiveness aiding 'selection'.

Once selected, GC from preovulatory follicles primarily secrete InhA and $\mathrm{P} 4$. This secretion in response to ActA is greatly enhanced during co-treatment with $\mathrm{LH}$ or FSH (greater than the sum of the responses to ActA and $\mathrm{LH} / \mathrm{FSH}$ alone; Lovell et al. 2002a); the present data suggest that this increased responsiveness to Act may in part be due to a LH/FSH stimulated increase in ActR. Consistent with this and with the above-mentioned functional evidence of synergism between ActA and gonadotrophins, ActA was recently shown to upregulate the expression of $\mathrm{LH}-\mathrm{R}$ and $\mathrm{FSH}-\mathrm{R}$ mRNA in preovulatory follicles (Johnson et al. 2006).

Although $\mathrm{LH}$ and $\mathrm{FSH}$ differentially regulate ActR and Bgly transcript levels (this study) and, reciprocally, ActA can increase $\mathrm{LH}-\mathrm{R}$ and FSH-R mRNA expression in prehierarchical follicle GC (Johnson et al. 2004, 2006), further work is required to understand how the balance of these, and most likely other, endocrine and paracrine signals allow the promotion of one 'selected' follicle into the preovulatory hierarchy.

GC inhibin B (InhB; $\alpha-\beta B$ dimer) protein levels (Lovell et al. 2003) peak in $6-8 \mathrm{~mm}$ prehierarchical follicles before falling steadily from the stage of follicle selection. Although InhB can associate with the ActRIls, association with co-receptor $\beta$ gly, which is also expressed (Sweeney \& Johnson 2005, Lovell et al. 2006) can greatly enhance their affinity for ActRIls (Lewis et al. 2000). However, as granulosal $\beta g$ ly mRNA expression (in this study) was an order of magnitude lower in prehierarchical follicles when compared with preovulatory follicles, InhB/Bgly may not be as an effective Act antagonist on prehierarchical GCs as InhA/ $\beta$ gly in preovulatory follicles. Unfortunately, InhB protein levels in GC-CM from $6-8 \mathrm{~mm}$ follicles were below the current assay detection limits. In a previous study, however, we were 
able to detect InhB in $\mathrm{CM}$ from $6-8 \mathrm{~mm}$ follicle wall explant cultures (Lovell et al. 2003). This suggests that a theca-derived factor present in follicle wall explant cultures (and absent in the GC mono-cultures) may play a role in upregulating $\operatorname{lnh} B$ production. ActA is a prime candidate here as ActA treatment increased inhibin/ activin $\beta B$-subunit mRNA level in GC from $6-12 \mathrm{~mm}$ follicles (Johnson et al. 2006). Further work is required to establish whether this increase in $\beta B$-subunit mRNA leads to increased InhB secretion although, as mentioned above, this is technically challenging due to the limited sensitivity of the current inhibin B assay.

InhA protein levels were below the assay detection limits in 'basal' CM from 6-8 mm GC (this study) and
6-8 mm follicle wall explants (Lovell et al. 2003) and in GC extracts from follicles $<9 \mathrm{~mm}$ (Lovell et al. 2003). Following gonadotrophin stimulation of $6-8 \mathrm{~mm}$ GC (this study) InhA secretion increased to detectable levels (albeit very much lower than from F1 GCs). The functional significance of the dramatic shift from $\operatorname{Inh} B$ to $\operatorname{Inh} A$ production around the point of follicle selection in vivo (Lovell et al. 2003) remains obscure and further work is warranted to investigate this striking phenomenon. Previous data in mammals indicate that $\beta$ gly potentiates the binding of both InhA and InhB to ActRIIA, with the complex being resistant to disruption by ActA. In contrast, only InhA binding to ActRIIB was significantly enhanced by Bgly (Chapman et al. 2002).

\section{A Prehierarchical follicle}

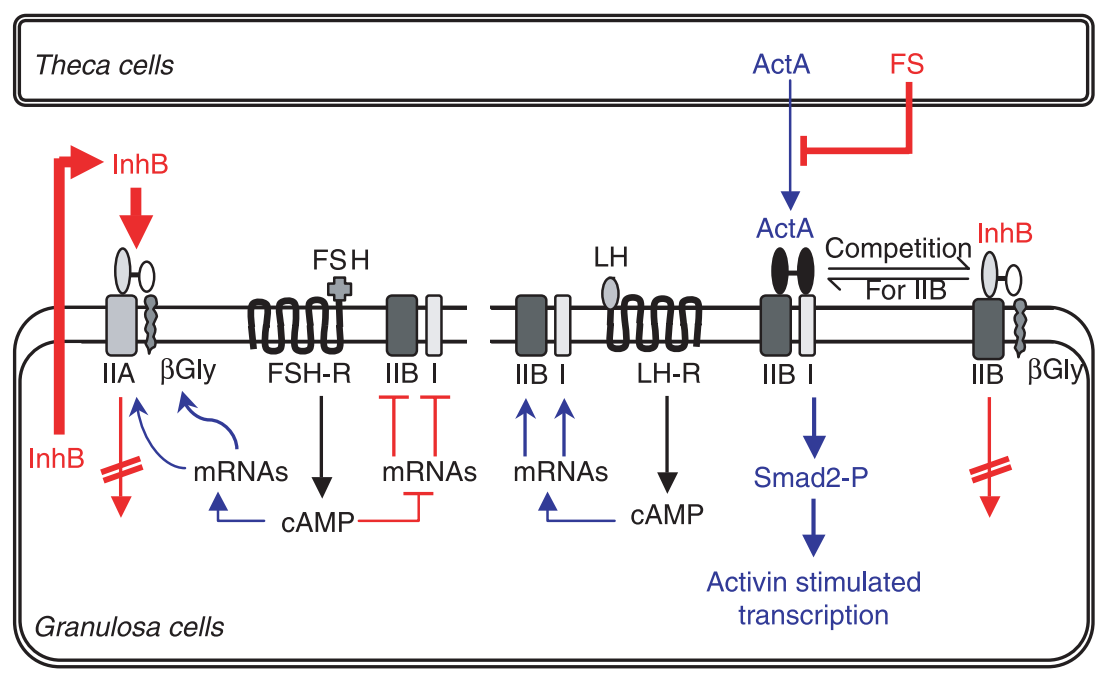

B Preovulatory follicle

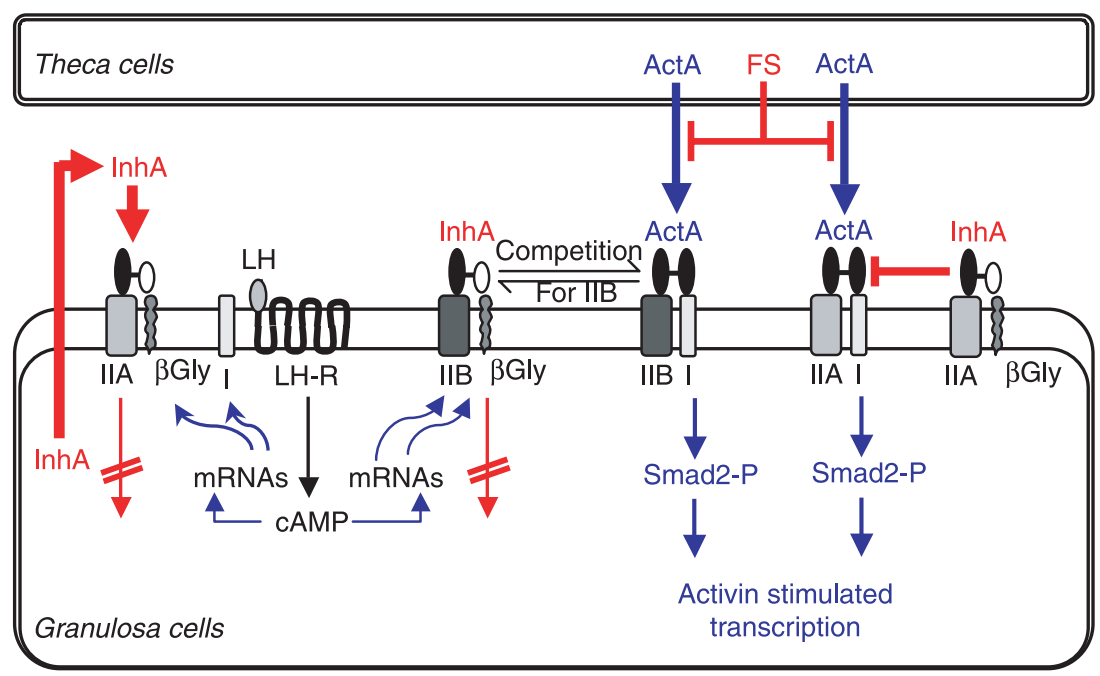

Key:
Figure 6 Proposed model showing events related to the regulation of Act signalling within the laying hen ovary. (A) In primarily FSH-responsive prehierarchical $(6-8 \mathrm{~mm})$ follicles FSH reduces ActRIIB (IIB) and ActRI (I) whilst stimulating ActRIIA (IIA) and BGly mRNA expression. High levels of granulosa-derived InhB can complex with IIA/ $\beta$ Gly, blocking thecal-derived ActA signalling. ActA action is further blocked by binding to FS (Schneyer et al. 2002). Upon acquiring LH-responsiveness, $\mathrm{LH}$ increases IIB and I mRNA expression allowing ActA to stimulate transcription through IIB and I via Smad2 (Johnson et al. 2004) as, unlike with IIA, ActA can compete with InhB/ $\beta$ Gly for binding with IIB (Chapman et al. 2002). (B) Following transition to preovulatory follicle status, InhA rather than InhB is produced by GC and there is an increase in ActA secretion without a rise in FS (Lovell et al. 2003). LH stimulation also increases I, IIB and $\beta$ Gly mRNA expression. ActA signalling is therefore regulated by complexing with FS and availability of I, IIA and IIB receptors, where IIA can be sequestered by binding with Inh/BGly. 
Therefore, it is tempting to speculate that, at the stage of follicle selection $(\sim 6-8 \mathrm{~mm})$ when granulosal InhB levels peak and InhA levels have yet to rise (Lovell et al. 2003), access of thecal-derived ActA to granulosal ActRIIB receptors would not be antagonised, allowing recruitment of ActRI to generate an active signalling complex (see Fig. 6).

In F1 GC, the expression of $\beta g$ ly and ActRIIB mRNA was significantly increased by $\mathrm{LH}$ and $\mathrm{FSH}$ treatment. InhA release was also significantly higher in F1 GC than in 6-8GC, reflecting ex vivo data (Lovell et al. 2003). Unlike ActA, InhA treatment alone has no effect on FSH$\mathrm{R}$ or LH-R mRNA expression in F1 GC (Johnson et al. 2006) supporting the notion that GC-derived InhA acts through antagonism of Act signalling by association with Bgly/ActRII.

Although only one ActRI subtype to date has been cloned in birds and investigated in this study (Accession number AJ318064), it does not exclude the possibility that multiple ActRI subtypes exist, as in mammals (Attisano et al. 1993, Tsuchida et al. 1995) or that ActRIls may also form signalling complexes with related TGF $\beta$-superfamily type-I receptors.

As with all studies investigating mRNA expression, the possibility cannot be excluded that the observed changes in steady-state mRNA transcript levels reflect changes in mRNA stability, rather than effects on gene transcription per se. Further, studies to verify that the changes in AcR and Bgly mRNA transcript levels reported here are accompanied by alterations in receptor protein expression would also be useful. However, as discussed earlier, this seems highly likely considering previous functional studies (Lovell et al. 2002a, Johnson et al. 2004, 2006, Woods \& Johnson 2005) which demonstrated interactions between the effects of ActA and gonadotrophins on hen GCs.

In conclusion, this study shows, for the first time in an avian species, that mRNA transcript levels for ActR and $\beta$ gly in TC and GC are modulated by gonadotrophins according to the cell-type and stage of follicle development. These findings, together with emerging evidence that follicles express a myriad of ligands, receptors and binding proteins, underscore the complexity of potential interactions between systemic and locally produced factors required to coordinate follicle progression into and through the preovulatory hierarchy.

\section{Acknowledgements}

We thank Dr A Parlow (NHPP) for supplying purified ovine LH and FSH, S A Feist for technical assistance and BBSRC for financial support (grant number 45/S17120). The authors declare that there is no conflict of interest that would prejudice the impartiality of this scientific work.

\section{References}

Abe Y, Minegishi T \& Leung PC 2004 Activin receptor signaling. Growth Factors 22 105-110.

Attisano L, Carcamo J, Ventura F, Weis FMB, Massague J \& Wrana JL 1993 Identification of human activin and TGF $\beta$ type I receptors that form heteromeric kinase complexes with type II receptors. Cell 75 671-680.

Bahr JM \& Johnson AL 1984 Regulation of the follicular hierarchy and ovulation. Journal of Experimental Zoology 232 495-500.

Chapman SC, Bernard DJ, Jelen J \& Woodruff TK 2002 Properties of inhibin binding to betaglycan, InhBP/p120 and the activin type II receptors. Molecular and Cellular Endocrinology 196 79-93.

Davis AJ \& Johnson PA 1998 Expression pattern of messenger ribonucleic acid for follistatin and the inhibin/activin subunits during follicular and testicular development in Gallus domesticus. Biology of Reproduction 59 271-277.

Davis AJ, Brooks CF \& Johnson PA 2001 Activin A and gonadotropin regulation of follicule-stimulating hormone and luteinizing hormone receptor messenger RNA in avian granulosa cells. Biology of Reproduction 65 1352-1358.

Donaldson CJ, Mathews LS \& Vale WW 1992 Molecular cloning and binding properties of the human type-II activin receptor. Biochemical and Biophysical Research Communications 184 310-316.

Etches RJ \& Duke CE 1984 Progesterone, androstenedione and oestradiol content of theca and granulosa tissue of the four largest ovarian follicles during the ovulatory cycle of the hen (Gallus domesticus). Journal of Endocrinology 103 71-76.

Gilbert AB, Evans AJ, Perry MM \& Davidson MH 1977 A method for separating the granulosa cells, the basal lamina and the theca of the preovulatory ovarian follicle of the domestic fowl (Gallus domesticus). Journal of Reproduction and Fertility 50 179-181.

Gilbert AB, Perry MM, Waddington D \& Hardie MA 1983 Role of atresia in establishing the follicular hierarchy in the ovary of the domestic hen (Gallus domesticus). Journal of Reproduction and Fertility 69 221-227.

Johnson AL 1993 Regulation of follicle differentiation by gonadotropins and growth factors. Poultry Science 72 867-873.

Johnson AL, Bridgham JT \& Wagner B 1996 Characterization of a chicken luteinizing hormone receptor (cLH-R) complementary deoxyribonucleic acid, and expression of CLH-R messenger ribonucleic acid in the ovary. Biology of Reproduction 55 304-309.

Johnson AL, Bridgham JT \& Jensen T 1999 Bcl-Xlong protein expression and phosphorylation in granulosa cells. Endocrinology $1404521-4529$.

Johnson AL, Bridgham JT \& Woods DC 2004 Cellular mechanisms and modulation of activin A and transforming growth factor $\beta$-mediated differentiation in cultured hen granulosa cells. Biology of Reproduction 71 1844-1851.

Johnson PA, Woodcock JR \& Kent TR 2006 Effect of activin A and inhibin A on expression of the inhibin/activin $\beta B$-subunit and gonadotropin receptors in granulosa cells of the hen. General and Comparative Endocrinology 147 102-107.

Kato M, Shimada K, Saito N, Noda K \& Ohta M 1995 Expression of P450 17 $\alpha$-hydroxylase and P450 aromatase genes in isolated granulosa, theca interna, and theca externa layers of chicken ovarian follicles during follicular growth. Biology of Reproduction $\mathbf{5 2}$ 405-410.

Knight PG \& Glister C 2003 Local roles of TGF $\beta$ superfamily members in the control of ovarian follicle development. Animal Reproduction Science 78 165-183.

Knight PG, Gladwell RT \& Lovell TM 2005 The inhibin-activin system and ovarian folliculogenesis in the chicken. In Functional Avian Endocrinology, pp 323-337. Eds A Dawson \& PJ Sharp. New Delhi, India: Narosa Publishing House.

Lewis KA, Gray PC, Blount AL, MacConell LA, Wiater E, Bilezikjian LM \& Vale W 2000 Betaglycan binds inhibin and can mediate functional antagonism of activin signalling. Nature 404 411-414. 
Lovell TM, Gladwell RT, Cunningham FJ, Groome NP \& Knight PG 1998 Differential changes in inhibin A, activin A, and total $\alpha$-subunit levels in granulosa and thecal layers of developing preovulatory follicles in the chicken. Endocrinology 139 1164-1171.

Lovell TM, Vanmontfort D, Bruggeman V, Decuypere E, Groome NP, Knight PG, Knight PG \& Gladwell RT 2000 Circulating concentrations of inhibin-related proteins during the ovulatory cycle of the domestic fowl (Gallus domesticus) and after induced cessation of egg laying. Journal of Reproduction and Fertility 119 323-328.

Lovell TM, Gladwell RT, Groome NP \& Knight PG 2002a Activin exerts differential effects on basal and gonadotrophin-induced secretion of inhibin A and progesterone by granulosa cells from preovulatory (F1-F3) follicles. Reproduction 124 649-657.

Lovell TM, Gladwell RT, Groome NP \& Knight PG 2002b Modulatory effects of gonadotrophins and insulin-like growth factor on the secretion of inhibin A and progesterone by granulosa cells from chicken preovulatory (F1-F3) follicles. Reproduction 123 291-300.

Lovell TM, Gladwell RT, Groome NP \& Knight PG 2003 Ovarian follicle development in the laying hen is accompanied by divergent changes in inhibin A, inhibin B, activin A and follistatin production in granulosa and theca layers. Journal of Endocrinology 177 45-55.

Lovell TM, Knight PG \& Gladwell RT 2006 Differential expression of mRNAs encoding the putative inhibin co-receptor (betaglycan) and activin type-I and type-II receptors in preovulatory and prehierarchical follicles of the laying hen ovary. Journal of Endocrinology 188 241-249.

Muttukrishna S, Fowler PA, Groome NP, Mitchell GG, Robertson WR \& Knight PG 1994 Serum concentrations of dimeric inhibin during the spontaneous human menstrual cycle and after treatment with exogenous gonadotrophin. Human Reproduction 9 1634-1642.

Nohno T, Noji S, Koyama E, Myokai F, Ohuchi H, Nishikawa K, Sumitomo S, Taniguchi S \& Saito T 1993 Expression patterns of the activin receptor IIA and IIB genes during chick limb development. Progress in Clinical and Biological Research 383B 705-714.

Ohuchi H, Noji S, Koyama E, Myokai F, Nishikawa K, Nohno T, Tashiro K, Shiokawa K, Matsuo N \& Taniguchi S 1992 Expression pattern of the activin receptor type IIA gene during differentiation of chick neural tissues, muscle and skin. FEBS Letters 303 185-189.

Philips DJ 2005 Activins, inhibins and follistatins in large domestic species. Domestic Animal Endocrinology 28 1-16.

Phillips DJ \& Woodruff TK 2004 Inhibin: actions and signalling. Growth Factors 22 13-18.

Richards JS 1994 Hormonal control of gene expression in the ovary. Endocrine Reviews 15 725-751.

Sauer MJ, Foulkes JA, Worsfold A \& Morris BA 1986 Use of progesterone 11-glucuronide-alkaline phosphatase conjugate in a sensitive microtitre-plate enzyme immunoassay of progesterone in milk and its application to pregnancy testing in dairy cattle. Journal of Reproduction and Fertility 76 375-391.

Schneyer AL, Rzucidlo DA, Sluss PM \& Crowley WF 2002 Characterization of unique binding kinetics of follistatin and activin or inhibin in serum. Endocrinology 135 667-674.

Slappey SN \& Davis AJ 2003 Expression pattern of messenger ribonucleic acid for the activin type II receptors and the inhibin/activin subunits during follicular development in broiler breeder hens. Poultry Science 82 338-344.

Stern CD, Yu RT, Kakizuka A, Kintner CR, Mathews LS, Vale WW, Evans RM \& Umesono K 1995 Activin and its receptors during gastrulation and the later phases of mesoderm development in the chicken embryo. Developmental Biology 172 192-205.

Sweeney SA \& Johnson PA 2005 Messenger RNA and protein expression analysis of betaglycan in the pituitary and ovary of the domestic hen. Biology of Reproduction 72 172-178.

Tannetta DS, Feist SA, Bleach ECL, Groome NP, Evans LW \& Knight PG 1998 Effects of active immunization of sheep against an amino terminal peptide of the inhibin $\alpha \mathrm{C}$ subunit on intrafollicular levels of activin A, inhibin A and follistatin. Journal of Endocrinology 157 $157-168$.

Tilly JL, Kowalski KI \& Johnson AL 1991 Stage of ovarian follicular development is associated with the initiation of steroidogenic competence in avian granulosa cells. Biology of Reproduction $\mathbf{4 4}$ 305-314.

Tsuchida K, Vaughan JM, Wiater E, Gaddy-Kurten D \& Vale WW 1995 Inactivation of activin-dependent transcription by kinase-deficient activin receptors. Endocrinology 136 5493-5503.

Woods DC \& Johnson AL 2005 Regulation of follicle-stimulating hormone-receptor messenger RNA in hen granulosa cells relative to follicle selection. Biology of Reproduction 72 643-650.

You S, Bridgham JT, Foster DN \& Johnson AL 1996 Characterisation of the chicken follicle-stimulating hormone receptor (cFSH-R) complementary deoxyribonucleic acid, and expression of cFSH-R messenger ribonucleic acid in the ovary. Biology of Reproduction 55 1055-1062.

Received 29 August 2006

First decision 10 October 2006

Revised manuscript received 23 February 2007

Accepted 6 March 2007 